\title{
The Role of Faculties of Education in Increasing Sustainable Environmental Awareness of Society
}

\author{
Abdullah KARATAŞ ${ }^{1}$
}

\begin{abstract}
Environmental problems show their negative effects globally today. Increasing pollution and changing climatic conditions reveal this situation clearly. Environmental problems, affecting the future of all living things, are connected with the incorrect relations between man and nature. People have become alienated from nature seeing it as an endless source and as a result nature has become a tool for achieving anthropocentric objectives. It can be said that such an anthropocentric view is the real cause of environmental problems, but human and nature harmony should be structured immediately because environmental problems have reached to serious position. Consequently, human being is a living creature and he needs healthy and reliable environment to live like all other creatures. Unless changing anthropocentric view of people towards nature, law and fines will also be helpless. At this point, education plays a very important mission. Because it is possible to change people's behavior and perspectives positively through education. For the creation of awareness about the importance of protecting environment in society, faculties of education as teacher training institutions are of great importance. Teachers, preparing generations for future and so shaping the future of a society, receive their professional qualification and requirements for becoming a teacher from faculties of education, so teacher candidates should be educated very well. Teacher candidates from all disciplines, educated with environmental consciousness, will be able to transfer this consciousness to their students when they graduate. Generations, given the love of nature at an early age by their teachers, can be eco-friendly individuals in the future and shed light on environmental problems. This theoretical study aims to put forward the role of faculties of education in increasing sustainable environmental awareness of society.
\end{abstract}

Key Words: Sustainable Environmental Awareness, Faculties of Education, Society

\section{Introduction}

Now generalizing environmental consciousness in society is an obligation rather than a necessity for a safer future. That's because, global environmental problems have begun to threaten human future. That's why communities have to adopt protecting and developing environmental values as a principle via essential laws and legal arrangements. Unless the viewpoint of the society towards 
environment has not been changed, the efforts to protect the environment are condemned to be disappeared. Society members, who protect environment because they are afraid, will continue using the environment insensibly for their own purposes. In this respect, Faculties of Education have to take an important responsibility. Faculties of Education are very important because of the fact that they are the institutes in which teachers are raised who direct society with the students they raised. If teacher candidates are given environmental awareness, they will transfer this awareness to their students when they begin working. If love of nature is instilled especially to preschool or primary school students, this will affect them throughout their lives and will lead them walk in safety to a sustainable future.

\section{The concept of environmental awareness}

Environmental concerns begun with the environmental awareness movement which burst upon the scene during, 1968-1970, as astronauts took the first photographs of Earth from outer space. Suddenly, during the 1970s, almost everyone became concerned about pollution, natural areas, population growth, food and energy consumption and biotic diversity (Marale, 2012: 869870). It can be said that today the most important reason of these environmental issues is the lack of harmony between human beings and nature. That's why; technology (Moore, 2008: 121) or laws (Simões, 2011) aren't enough to solve environmental problems which have social, economic and political dimensions. Unless the environmental awareness of people has been developed, their viewpoint towards environment cannot be changed. As a result, human-induced environmental problems will continue affecting the entire global creatures in a negative way.

The aim of environmental awareness is, as many scientists emphasize, environmental knowledge, attitude towards environment and useful behavior towards environment. These can be explained shortly as (Erten, 2012: 91):

- Environmental knowledge: Environmental problems, the solution sought to these problems, ecological advancements and the entire information about nature.

- Attitude towards environment: Environmental problem based fear, anger, anxiety, value judgment and positive or negative attitudes of the individuals towards useful behaviors to solve environmental problems.

- Useful behavior towards environment: Real, useful environmentally friendly behaviors to protect nature.

In the light of the above statements environmental awareness can be expressed as follows(Encyclopedic Dictionary of Landscape and Urban Planning, 2010: 294): environmental awareness is informed comprehension and pronounced 
responsibility for environmental problems on the part of citizens and those responsible in administration and industry. It is based upon an understanding of the threats imposed upon fundamental natural resources and the willingness to implement remedial measures. According to Bharucha (2005); as the Earth's natural resources are rapidly dwindling and our environment is being increasingly degraded by human activities, it is evident that something needs to be done. Nature is for all creatures and all of us should keep and devolop it for a safer future. This can only be made possible through environmentals awareness. Environmental awareness which is necessary in order to overcome the global environmental problems, can be given to society through education. Chapter 36 of Agenda 21 (UNCED, 1992) suggests that education is critical for promoting sustainable development and improving the capacity of the people to address environment and development issues. Both formal and non-formal education are indispensable to changing people's attitudes so that they have the capacity to assess and address their sustainable development concerns. It is also critical for achieving environmental and ethical awareness, values and attitudes, skills and behaviour consistent with sustainable development and for effective public participation in decision-making. Giving awareness about sustainability through education is so important that universities have launched a new movement in all European countries.

In Europe, Copernicus-Campus is a university network where, as a response to the Earth Summit in Rio de Janeiro in 1992, the Copernicus University Charter for Sustainable Development was signed to raise consciousness within the European universities of collaborating to preserve the future. By now, more than 320 universities and higher education institutions from 38 countries across Europe have signed the Copernicus Charter to declare that they will give sustainable development an important place in their activities. This implies that in the university curricula, institutional management and services concerning local/regional society as well as the responsible balance of economical, ecological and societal/cultural aspects must be considered (Burkhardt-Holm and Chebbi, 2008: 137). With university

\section{Sustainability as a concept and sustainable development}

Life support systems include atmosphere, water and soil all of these need to be helthy, meaning that their environmental servive capacity must be maintained. A healthy ozone shield, for example, prevents damage by ultraviolet $\mathrm{b}$ radiation to biota such humans and crops. Continuous depletion or damage by human activities to irreplaceable and unsubstitutable environmental services would be incompatible with sustainability (Goodland, 1995: 2). Globally, academics, industry professionals, governments and societies are directing their 
attention to the issue of global warming and are engaged in efforts to conserve the Earth's natural resources. This has led to the introduction of the concept of sustainability (Fairer-Wessels and Malherbe, 2012: 93). Sustainability starts from the view that there are physical and environmental limits to the resources of the Earth (Dresner, 2002), so as human beings we shouldn't forget Mahatma Gandhi's principle of enoughness: "The earth provides enough to satisfy every person's need but not every person's greed.” (Miller and Spoolman, 2008: 335). Therefore, everyone in the society should internalize sustainability.

Sustainability is based on a simple principle: Everything that we need for our survival and well-being depends, either directly or indirectly, on our natural environment. Sustainability creates and maintains the conditions under which humans and nature can exist in productive harmony, that permit fulfilling the social, economic and other requirements of present and future generations. Sustainability is important to making sure that we have and will continue to have, the water, materials, and resources to protect human health and our environment (EPA). Sustainability has so important today that almost all countries take into consideration it for their development.

The "Brundtland Report", as it became known, authored by Dr. Gro Harlem Brundtland (Director General of the World Health Organization), explicitly introduced the term "Sustainable Development" as a conceptual bridge to bring together environmentalists and industrialists in 1987. A key part of the Brundtland report was the identification of six elements considered important in a successfull sustainable development policy (Strong and Hemphill, 2008: 2):

- Reviving economic growth,

- Changing the quality of growth,

- Meeting essential needs for jobs, food, energy, water and sanitation,

- Ensuring a sustainable level of population,

- Reorienting technology and managing risk,

- Merging environment and economics in decision-making process.

Sustainable development can be described as being underpinned by an ethic of solidarity, equality and mutual respect among people, countries, cultures and generations; it is development in harmony with nature, meeting the needs of the present generation without compromising the ability of future generations to meet their own needs (UNECE). Sustainable development is the process by which we move towards sustainability. It is underpinned by four main principles (Bhamra and Lofthouse, 2012: 14-15):

- Equity Today: "Equity Today" is the principle of equity between different groups of people alive today. It implies that consumption and production in one community should not undermine the ecological, social and economiz basis for other communities to maintain or improve their quality of life. 
- Environmental Justice: "Environmental Justice" can be described as giving equal access to a clean environment and equal protection from possible environmental harm irrespective of race, income or class or any other differentiating feature of socio-economic status.

- Intergenerational Equity: "Intergenerational Equity" is the principle of equity between people alive today and future generations. The implication is that unsustainable production and consumption by today's society will degrade the ecological, social and economic basis for tomorrow's society, whereas sustainable development involves ensuring that future generations will have the means to achieve a quality of life equal to or better than today's.

- Stewardship: Stewardship can be described as taking responsibility for the rest of life on the earth. As sustainable development recognises natural systems underpin all human systems and therefore human society can not function without them and there are clearly limits to ways in which natural systems can be exploited.

All of these principles can be applied by community members who have enough environmental awareness. Education is the key concept here. Especially, theoretical and practical environmental education for teacher candidates is crucial, because after graduation these candidates will transmit their high level of environmental awareness to their students and these students will construct environmentally conscious society. According to Joseph (2009) environmental education can meet the challenges of a rapidly changing world. Environmental education is the education for sustainable and ethical development, both at a local and global level. It is environmental education that will prepare the next generation to plan appropriate strategies for addressing issues such as urban sprawl at al local level while stil maintaining focus of the challenges that globalization presents on an international level. Knowledge about the environment promotes attitudinal and behavioural change. Therefore, environmental education is an agent of change and a step toward community empowerment. In this context, faculties of education are of great importance.

\section{The importance of faculties of education for the society in terms of sustainability}

Schools are very important for a nation's future economic, civic, social and cultural development (Taubman, 2011: 161). They have great influence for the members of a society. Organized form of education takes place in schools, so schooling takes up a large amount of young people's time. School hours are more important as socializing agents for most children, given the amount of attention school requires and the highly involving competitions and group interactions that occur there (Brint, 2006: 1-3). In this context, schools are the 
most powerful agent of socialization (Berns, 2009: 233). Teachers who are the key elements of this socialization as the practitioners of education in schools are of great importance, because the teachers, performing educational goals of schools, play an important role in shaping the future of a society (Berns, 2009: 233). This is because; they raise the individuals and shape the society, but teachers' education is as important as shaping it. The institutions, in which the performers of the education namely the teachers are raised, are Faculty of Education, so Faculties of Education are crucial for society. Raising teacher candidates ideally is the major condition in forming a conscious society. Effective teachers are crucial to the development of quality teaching and learning in schools (Kennedy and Lee, 2008: 130).

School teaching serves society and it is within the society, so it requires selfdevotion, patience and commitment. For this reason, in Turkey "Community Service Practices" (CSP) course is being given to teacher candidates by Faculties of Education in order to gain experience about their profession and increase sense of responsibility. Via these courses teacher candidates raise awareness of the society in different terms with their own activities and present their own works. Among these activities instilling environmental awareness to the society is very important, because raising environmental awareness of the society can be expressed as the most effective way to overcome today's environmental crisis. "Community Service Practices" courses, conducted by Niğde University Faculty of Education in Turkey can be exemplified to the activities done for raising environmental awareness of the society. In this context, teacher candidates conduct some projects. Some of these projects done by teacher candidates of Niğde University Faculty of Education, Department of Primary School Teaching are shown in Table 1 (Talas and Karatas: 2012: 116-117):

Table 1: Projects of Teacher Candidates of Niğde University Faculty of Education

\begin{tabular}{|l|c|l|}
\hline \multicolumn{1}{|c|}{$\begin{array}{l}\text { Project } \\
\text { Name }\end{array}$} & $\begin{array}{l}\text { Academic } \\
\text { Year }\end{array}$ & \multicolumn{1}{|c|}{ Explanations } \\
\hline $\begin{array}{l}\text { Erosion Control } \\
\text { and Afforestation }\end{array}$ & $2009-2010$ & $\begin{array}{l}250 \text { saplings have been provided from Niğde Directorate of } \\
\text { Environment and Forestry and they have been planted to } \\
\text { Altunhisar district of Niğde. }\end{array}$ \\
\hline Windbreak Project & $2009-2010$ & $\begin{array}{l}250 \text { saplings have been provided from Niğde Directorate of } \\
\text { Environment and Forestry and they have been planted to } \\
\text { Altunhisar district of Niğde. }\end{array}$ \\
\hline $\begin{array}{l}\text { Awareness for } \\
\text { Recycling }\end{array}$ & $2010-2011$ & $\begin{array}{l}\text { The students of Niğde Dumlupinar Primary School have been } \\
\text { enlightened about the importance of recycling in terms of } \\
\text { environment. }\end{array}$ \\
\hline $\begin{array}{l}\text { Reactivate Your } \\
\text { Batteries }\end{array}$ & $\begin{array}{l}\text { The community has been enlightened well rounded about the harms } \\
\text { of waste batteries by taking support of Niğde Municipality and local } \\
\text { TV station. Battery collection boxes have been made and delivered to } \\
\text { ten different schools in Niğde. Some useful information has been }\end{array}$ \\
\hline
\end{tabular}




\begin{tabular}{|c|c|c|}
\hline & & given to students with the help of posters and slides. \\
\hline $\begin{array}{l}\text { Developing our } \\
\text { Future Together }\end{array}$ & $2010-2011$ & $\begin{array}{l}1000 \text { saplings have been provided from Niğde Directorate of } \\
\text { Environment and Forestry and they have been planted to Niğde } \\
\text { University Central Campus with the participation of students, } \\
\text { Niğde University Rector, various faculty members and local press. }\end{array}$ \\
\hline $\begin{array}{l}\text { Consciousness } \\
\text { Recovery of Primary } \\
\text { School Students In } \\
\text { Planting }\end{array}$ & $2010-2011$ & $\begin{array}{l}30 \text { saplings have been provided from Niğde Directorate of } \\
\text { Environment and Forestry and they have been planted to the } \\
\text { garden of Niğde Zahide Sefer Primary School with students. } \\
\text { Students have been enlightened about the benefits of trees. }\end{array}$ \\
\hline $\begin{array}{l}\text { Waste Oil is Ours } \\
\text { and Clean Water is } \\
\text { Yours }\end{array}$ & $2010-2011$ & $\begin{array}{l}\text { By taking the Support of Niğde Municipality, brochures and posters } \\
\text { about the harms of waste oil to the water supplies and nature have } \\
\text { been distributed. }\end{array}$ \\
\hline Planting Trees & $2010-2011$ & $\begin{array}{l}75 \text { saplings have been provided from Niğde Directorate of } \\
\text { Environment and Forestry and they have been planted to Niğde } \\
\text { University Central Campus with the participation of Niğde } \\
\text { University Faculty of Education Dean, project director, primary } \\
\text { school teaching students and local press. }\end{array}$ \\
\hline $\begin{array}{l}\text { Planting and Park } \\
\text { Works }\end{array}$ & $2010-2011$ & $\begin{array}{l}250 \text { saplings have been planted to a park area and school garden with } \\
\text { the participation of Niğde } 19^{\text {th }} \text { May Primary School managers, teachers } \\
\text { and students with the contribution of Niğde Municipality Parks } \\
\text { Department. }\end{array}$ \\
\hline $\begin{array}{l}\text { Importance of } \\
\text { Recycling }\end{array}$ & $2010-2011$ & $\begin{array}{l}\text { Recycling bins have been put in the garden of Niğde } \\
\text { University Faculty of Education and Sabanci Girls' Dormitory } \\
\text { with the support of Niğde Municipality. The students of } \\
\text { Niğde } 75^{\text {th }} \text { Year Mustafa Altuncu Primary School have been } \\
\text { enlightened about recycling and environmental pollution. }\end{array}$ \\
\hline $\begin{array}{l}\text { One Pen One } \\
\text { Student }\end{array}$ & $2010-2011$ & $\begin{array}{l}\text { The slogan of the project "One Pen One Student" have been } \\
\text { pressed on } 1000 \text { pens. These pens have been sold to the } \\
\text { students and instructors and then one microscope, ten lames } \\
\text { and ten lamelles have been bought with the profit. They were } \\
\text { presented to both Atatürk Primary School and Cumhuriyet } \\
\text { Primary School in Kecikale town of Niğde. } 24 \text { packages of A4 } \\
\text { papers have been presented to another village school. }\end{array}$ \\
\hline $\begin{array}{l}\text { Education } \\
\text { Volunteers' Night }\end{array}$ & 2010-2011 & $\begin{array}{l}\text { With the profit of the play that has been performed by Education } \\
\text { Lovers Theatre Group, Niğde Hüdavend Hatun School for the } \\
\text { Hearing Impaired has been painted and two photocopiers have } \\
\text { been presented to this school. }\end{array}$ \\
\hline $\begin{array}{l}\text { Sister School } \\
\text { Project }\end{array}$ & $2010-2011$ & $\begin{array}{l}\text { Niğde Sakarya Primary School has been included in sister } \\
\text { school project, then poor students have been determined. } \\
\text { These students have been helped with shoes, clothes, books } \\
\text { and study time. }\end{array}$ \\
\hline $\begin{array}{l}\text { Drink Two Glasses } \\
\text { of Milk for a } \\
\text { Healthy Life }\end{array}$ & 2010-2011 & $\begin{array}{l}\text { Some milk has been distributed to Niğde Behzat Ecemiş } \\
\text { Primary School Students, then they have been enlightened } \\
\text { about the importance of the milk in terms of human health. }\end{array}$ \\
\hline
\end{tabular}

Reference: Talas and Karatass, 2012: 116-117 
As it can be seen in Table 1, these activities carried by teacher candidates are really important in terms of making the society conscious and making the teacher candidates realize their responsibilities for society and environment. For cleaner and healthier environment, the activities may enable them to gain experience and become more useful in their future jobs. Raising teacher candidates' environmental awareness via applied environment education lessons will enable the society to have greener, healthier and more sustainable future.

\section{Conclusions}

As environmental disasters occur with increasing frequency, their impact also grows more severe. There are two kinds of environmental disasters: man made or human induced and natural. Natural disasters are referred to as acts of "Mother Nature" or "acts of God". They constitute a category of environmental events that periodically subject human systems to a wide range of disruptions and increased stress (Kalayjian, 1994:155). The general perception is that disasters are the result of natural phenomena. Historically, this has been predominantly so, but over the past 200 years, the impact of human existence and activities has altered the situation substantially. Human activities can lead to disasters when they cause widespread ill health, loss of life an irreversible destruction of the environment. This can happen in a number ways, as a result of direct and indirect human action (McDonald, 2003: 159). Increasing pollution, climate change, deforestation, endangered species are all indicators of human induced disasters. Here, environmental education has a key role. According to Yalçınkaya (2013), environmental education is a process that begins in the family, becomes systematic at school and continues throughout life. This process is very important for a livable world. The aim is to make people protect the environment they live in. Raising teacher candidates for that purpose in Faculty of Education will change the viewpoint of the society in a positive way. That is because, the children who are sent to schools and are raised with nature love, will enlighten many environmental problems as the parents or individuals of the future. According to Alpagut (1997: 118); it is possible to benefit from the educational programs after a few generations when they were applied on little children. With the education of grownups, nature consciousness will be widespread and the viewpoints of the society will be checked and appropriate policies will be produced. In this way a society which consists of individuals having sustainable environmental awareness will be obtained and future generations will be enabled to live in a safer environment. 


\section{References}

Alpagut, B. (1997). Doğal Çevre ve İnsanın Evrimi. Ruşen Keleş(Ed.), İnsan Cevre Toplum içinde (s.113-119). Ankara: İmge Kitabevi.

Berns, R. M. (2009). Child, Family, School, Cmmunity, Socialization and Support. Belmont, USA: Cengage Learning.

Bhamra, T. and Lofthouse, V. (2012). Design for Sustainability: A Practical Approach, UK: Gower Publishing, Ltd.

Bharucha, E. (2005). Textbook of Environmental Studies for Undergraduate Courses. Hyderabad, India: University Press.

Brint S. G. (2006). Schools and Societies. California, USA: Stanford University Press.

Burkhardt-Holm, P. \& Chebbi, C.(2008). Master's Degree in Sustainable Development in Switzerland, The First Master Course Comprising Three Faculties. Environmental Science and Pollution Research, Volume: 15, Issue: 2, p.136-142

Dresner, S. (2012). The Principles of Sustainability. London, UK: Routledge.

Encyclopedic Dictionary of Landscape and Urban Planning. (2010). Retrieved 29 February,2013 from http://link.springer.com/search?query=environmental +awareness

EPA (Environmental Protection Agency) Web Page. Retrieved 16 February, 2013 from http://www.epa.gov/sustainability/basicinfo.htm

Erten, S. (2012). Environmental Consciousness among Turkish and Azeri Candidate Teachers. Education and Science. Vol. 37, No 166, p. 88-100.

Fairer-Wessels, F. A.\& Malherbe, N. (2012). Sustainable Urban Event Practice: the Role of Corporate Sponsors within Gauteng. Urban Forum, March, Volume: 23, Issue: 1, p.93-106.

Goodland, R. (1995). The Concept of Environmental Sustainability, Annual Review of Ecology and Systematics, Vol. 26, p. 1-24.

Joseph, B. (2009). Environmental Studies, New Delhi, India: Tata McGraw-Hill Publishing Company Ltd.

Kalayjian, A. S. (1994). Emotional and Environmental Connections: Impact of the Armenian Earthquake. In Eleanor Schuster \& Carolyn Brown (Eds.), Exploring Our Environmental Connections (p. 155-180). New York, USA: Jones \& Bartlett Learning.

Kennedy, K. J. \& Lee, Z. (2008). The Changing Role of Schools in Asian Societies: Schools for the Knowledge Society. New York, USA: Routledge.

McDonald, R. (2003). Introduction to Natural and Man-made Disasters and Their Effects on Buildings. Oxford, UK: Routledge.

Miller,G. T. Jr. \& Spoolman S. E. (2008). Sustaining the Earth: An Integrated Approach, Canada: Cengage Learning.

Moore, S. A. (2008). Waste Practices and Politics: The Case of Oaxaca, Mexico. In David V.

Carruthers (Ed.), Environmental Justice in Latin America Problems, Promise, and Practice (p. 119136). London, England: The MIT Press

Marale, S. M. (2012). Shifting Role of Ecology In Solving Global Environmental Problems: 
Selected Practical Tools. Environment, Development and Sustainability, December, Volume:14, Issue: 6, p. 869-884.

Simões, S. (2011). How green are Brazilians? Environmental V alues, Attitudes and Behavior in Brazil. Retrieved 21 February, 2013 from http://sedac.ciesin.columbia.edu/ openmeeting/downloads/1002255746_presentation_ thegreeningofbrazilians.doc

Strong, W. A. \& Hemphill, L. (2008). Sustainable Development Policy Directory, Oxford, UK: Blackwell Publishing Ltd.

Talas, M. \& Karataş, A., (2012), The Importance of Community Service Practices Course inImproving Environmental Awareness and the Example of Niğde University Faculty of Education. Zeitschrift für die Welt der Türken, Journal of World of Turks, Vol. 4, No. 1, p. 107-124.

Taubman, P. (2011). Making Nothing Happen. In Lyn Yates and Madeleine Grume (Eds.),

World Yearbook of Education 2011: Curriculum in Today's World: Configuring Knowledge, Identities, Work and Politics (p. 157-170). Canada, USA: Taylor \& Francis.

UNCED (The United Nations Conference on Environment and Development), (1992)

Agenda 21, Chapter 36: Promoting Education, Public Awareness and Training, Retrieved 27 February, 2013 from http://habitat.igc.org/agenda21/a21-36.htm

UNECE ( United Nations Economic Commission for Europe), Retrieved 02 March, 2013 from http://www.unece.org/environmental-policy/areas-of-work/education-for-sustainable-developmentesd/about-us/introduction.html

Yalçınkaya, E. (2013). Environmental Issues to 8th Grades Elementary Education Students:

A Qualitative Study. Marmara Geographical Review, Vol. 27, January, p. 416-439. 